\title{
Looking for Children Left Behind: American Language Policies in a Multilingual World
}

\author{
Suparna Bose
}

\begin{abstract}
This article discusses ramifications of the Census 2010 reports, a substantial increase in language-minority populations, and an atmosphere of mistrust towards bilingual and bidialectal people felt by mainstream society in America. It also examines the process of assimilation, immersion, and silencing of immigrant/minority cultures, resulting in the loss of their identity. The pejorative effects of this can be observed in the lower self-esteem, lower grades and continuing school dropout rates of languageminority children today. By looking at models of bilingual or multilingual countries, the article also highlights that lawmakers and communities recognize the cultural histories of bilingual/multilingual learners and acknowledge the benefits of bilingualism. It goes on to recommend ways to increase the marketability of future American citizens, both monolingual and bilingual, in an era of globalization and plurality of the English language.
\end{abstract}

\section{Introduction}

The Census 2010 reports showed some noteworthy changes in the population distribution of different ethnicities in the United States, and an unprecedented growth in the minority population. Between 2000 and 2010, the Hispanic population grew by 43 percent-rising from 35.3 million in 2000, when this group made up 13 percent of the total population, to 50.5 million. The Asian population also increased by 43 percent between 2000 and 2010, moving up from about 4 percent of the total population in 2000 to about 5 percent in 2010. The Native Hawaiian and Other Pacific Islander population, the smallest major race group, also grew substantially between 2000 and 2010, increasing by more than one third. This population numbered 398,835 in 2000 , rising to 540,013 in 2010 , with its proportion of the total population changing from 0.1 percent to 0.2 percent. An 18 percent growth in the American Indian and Alaskan Native population occurred between 2000 and 2010. This population, also relatively small numerically, maintained its proportion of the total population between decennial censuses $(0.9$ percent) while growing from 2.5 million to 2.9 million. The Black population rose from 34.7 million in 2000 to 38.9 million in 2010, increasing 12 percent between 2000 and 2010. The White population increased from 211.5 million in 2000 to 223.6 million in 2010, an increase of 5.7 percent; it was the only major race group to experience a decrease in its proportion of the total population. 
Also, a separate segment in the 2010 Census, entitled 'Geographic Distribution of the Minority Population' recorded that over one third of the US population reported their race and ethnicity as something other than non-Hispanic White. This group, referred to as the "minority" population for this report, increased from 86.9 million to 111.9 million between 2000 and 2010, representing a growth of 29 percent over the decade. Moreover, a comparative study (see Figure 1) of the present total population of the USA with that of its projected population in 2050 would show that numerically the "minority" population was set to overtake the non-Hispanic White segment. Data for Figure 1 was taken from Table 4 "Projections of the Population by Sex, Race, and Hispanic origin for the United States: 2010 to 2050" (NP 2008-T4) (United States Census Bureau, Population Division, 2008).

\begin{tabular}{|lll|}
\hline Population by Race alone & $\mathbf{2 0 1 0}$ (Actual) & $\mathbf{2 0 5 0}$ (Projected) \\
\hline White & 246,630 & 324,800 \\
\hline Non-Hispanic White & 200,853 & 203,347 \\
\hline Black & 39,909 & 56,944 \\
\hline $\begin{array}{l}\text { American Indian and Alaskan Native } \\
\text { American }\end{array}$ & 3,188 & 5,462 \\
\hline Asian & 14,415 & 34,399 \\
\hline Native Hawaiian and Pacific Islander & 592 & 1,134 \\
\hline Hispanic, belonging to any race & 49,726 & 132,792
\end{tabular}

Figure 1. Comparison of the Distribution of the US Population by Race Alone, in 2010 and 2050.

When observed together with the results of the 2010 American Community Survey 1-Year Estimates, "Language Spoken at Home by Population 5 Years and Older" (United States Census Bureau Factfinder), some intriguing facts come to light. English continued to be the most prevalent language spoken in the US by $79.4 \%$ of the people (only speaking English), compared to $20.6 \%$ speaking languages other than English. $12.8 \%$ of the population spoke Spanish or Spanish Creole, $3.7 \%$ spoke other Indo-European languages, $3.2 \%$ spoke Asian and Pacific Island languages and $0.9 \%$ spoke other languages. As the numbers of "minority" speakers (in Spanish, Spanish Creole, other Indo-European, Asian and Pacific Island languages) increase, as shown in Figure 1, there would be a significant and concomitant rise in the population of bilinguals in this country, noted in Figures 2 and 3 below (data from US Census Bureau, Population Division, 2008). 


\section{US Population 2010}

- Bilingual/Bidialectal $\quad$ Monolingual

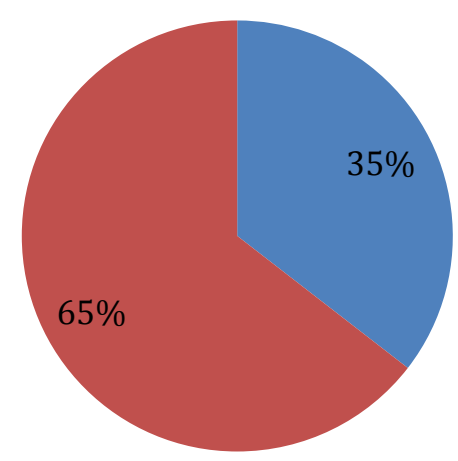

Figure 2. Distribution of Monolingual and Bilingual/Bidialectal Population in the US in 2010

\section{US Population 2050}

- Bilingual/Bidialectal $\quad$ Monolingual

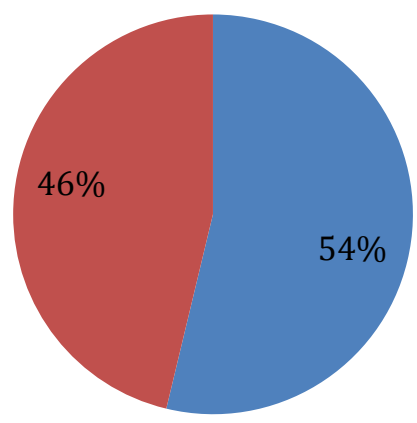

Figure 3. Distribution of Monolingual and Bilingual/Bidialectal Population in the US in 2050 


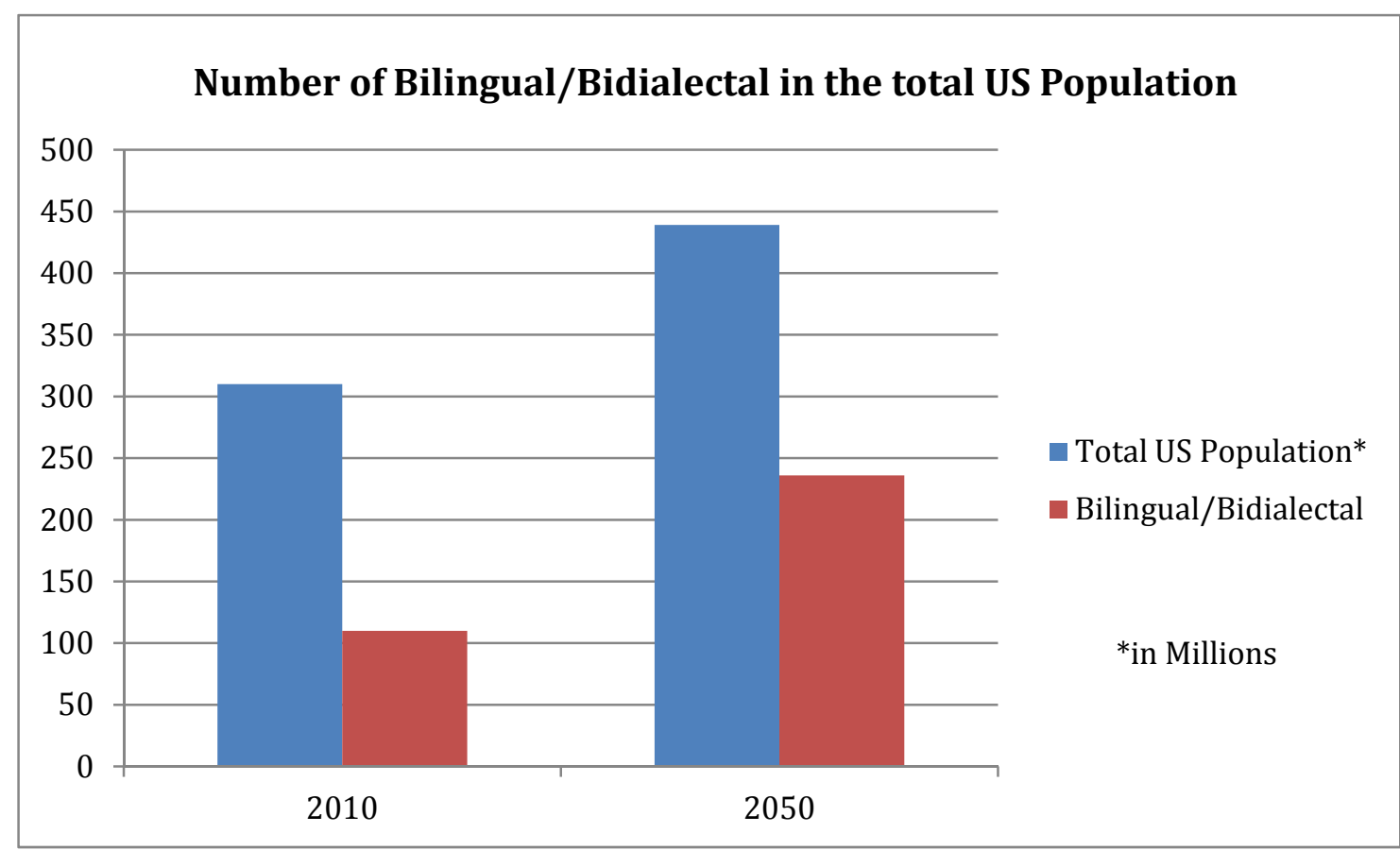

Figure 4. A Comparison of Numbers of Bilinguals/Bidialectals in the US in 2010 and 2050.

The changing demographics of the future must be matched with an accommodating education policy, not a one-size-fits-all type. In this context, this article will define some basic terms-“bilingual", "bidialectal", "voluntary and involuntary immigrants", "minorities"— that will play a vital role in the arguments put forward.

\section{Bilingualism, Bidialectalism and Immigration}

This article will use the term "bilingual" or "bilingual speaker" following Colin Baker's (1993) definition of "bilingualism as a group or societal possession" (p. 4) and will refer both to 1) "voluntary immigrants" speaking languages different from English like, Spanish, Portuguese, French, German, Dutch, Chinese, Korean, Japanese, Vietnamese, Arabic, etc.; and 2) "involuntary immigrants" through a process of colonization and/or annexation, speaking dialectal varieties of English like AfricanAmerican English Vernacular (AAEV), Hawaiian Creole English (HCE) or Chicano English as following John U. Ogbu's (1999) definition of "voluntary" and "involuntary" immigrants (p. 153).

The term "Minorities" had been defined as 1) voluntary immigrants who moved to the US in search of better opportunities in life, for example, immigrants from Asia, Africa, Central or South America; and 2) involuntary immigrants or nonimmigrants who were made a part of the US against their will through annexation, colonization or slavery, for example, the native Americans and Alaskans, the early Mexicans of the Southwest, native Hawaiians, Puerto Ricans and African-Americans. Many of these groups, as bilinguals and/or bidialectals, experience a sense of marginalization stemming from their immigration (whether voluntary or involuntary) and reinforced by their loss of identity (Ogbu, 1999). 
LOOKING FOR CHILDREN LEFT BEHIND PAGE | 165

\section{Loss of Identity and Self and Social Marginalization in Bilinguals and Bidialectals}

Before the twentieth century, instead of encouraging language diversity, the American government adopted a policy of "quick assimilation into English" (Nieto, 2009 , p. 61) when dealing with immigrant language-minority populations to ensure easier governance, using English and Anglicization as a unifying force. That resulted in a loss of identity among the immigrant or language-minority speakers; their forced Anglicization in immersion-type schooling; and finally, frustration of the bilingual students in abandoning their own language and learning the new language. The bilingual speaker was left with a feeling of ambivalence "toward one's own native language, the value of one's cultural background, and, ultimately, the value of oneself" (Nieto, 2009, p. 61).

It could be argued that the place of language in the cultural life of each social group was interdependent with the habits and values of behavior shared among members of that group (Heath, 1996). Hence, when one's native language was taken away and another language was imposed, the collective identity of the colonized/immigrant/minority-language group took a beating. The result of this ambivalence could be observed in the studies of many researchers. It became a devaluation of the "self" by virtue of which the colonizer's or majority-language group's language was imposed on the colonized or the minority speakers until the latter found the language of the former to be superior: "Blacks found White speakers of SAE to be more attractive, kind, and articulate. In fact, Black participants were much harsher critics of BE than were Whites" (Billings, 2000, pp. 74-77).

Language might become an even greater source of collective disgrace, "a collective shame we African-Americans have internalized about our very beings" (Delpit, 2002, p. 35). However, this feeling was not limited to African-Americans alone. It was shared by other minority communities as well. Victoria-Maria Macdonald (2004) quoted the 1969 manifesto "El Plan de Santa Barbara" to describe the Mexican-American: "The Mexican-American is a person who lacks respect for his culture and ethnic heritage. Unsure of himself, he seeks assimilation as a way out of his 'degraded' social status"' (p. 260).

This collective sense of lowliness, degradation, shame and inferiority, coexisting with the silencing of immigrant or minority languages, did not improve the immigrant or minority student's facility in English. Instead, its pejorative effect could be observed in the school dropout rates and lower grades of such students. Recent research has shown that the Asian-American community, stereotypically regarded as a model minority group because of their success and upward social mobility, had its share of school dropouts (Lew, 2004; Min, 1996). Moreover, such minority speakers tended to associate successful members of their community with whiteness, and their own low socioeconomic status with other minorities of color with a similar social status (Lew, 2004).

However, merely assimilating by learning to speak English was not enough. Mastering Standard American English (SAE) was the key. Ogbu (1999) had 
described that in a bidialectal speech community, one dialect ranked higher than the other on political grounds. This argument could be extended to include the bilingual speech communities as well, who spoke distinctively different dialects of English. This article would like to connect that standpoint with the "unquestioned association between so-called good English and good character" (Spiecher and Bielanski, 2000, p. 158) and explain how the practice of Standard Ideology "justifie[d] discriminatory practices in the schools, the workplace and society" and "privilege[d] certain usages and stigmatize[d] the others, adversely affect[ing] the lives of those who use stigmatized forms" (p. 157). Social mobility was inextricably linked with the use of SAE, the language of the mainstream or the majority, the language associated with whiteness. The bidialectal and the bilingual speaker have been excluded by virtue of the languages and dialects that they spoke. The same tool for assimilation that alienated them from their language now became a stigma of otherness.

The paradox of this situation lay rooted in the past, in the inconsistent language policies of the last couple of centuries. Analyzing historical events, one can discern two contradictory influences having contributed to this uncertainty. Throughout its history, the government has imposed English on voluntary and involuntary immigrants alike. On the other hand, democratic and libertarian ideals and a welcoming immigration policy have emphasized the freedoms of the individual and the model of America as the land of dreams and opportunity. The key to future educational reform lies in charting a middle path between these divergent stances.

\section{History of the Dominance of English in the US}

\section{Annexation Policies of the Nineteenth Century}

The American government imposed the use of English among Native Americans and inhabitants of the Southwest territories, as well as on the African-Americans who were slaves. Then it also used different strategies to increase the influx of Englishspeaking people into the Southwestern states. In some areas, the Spanish-speaking zones were split. In others, statehood was deferred until there were sufficient numbers of English speakers in the state. California gained statehood in 1850; Nevada in 1864; Colorado in 1876; Utah in 1896; New Mexico and Arizona in 1908 (Nieto, 2009, p. 62).

\section{Legislations, the First World War and the Rise of American Nationalism}

The Nationality Act of Texas (1906) stipulated English to be the only language taught in schools and highlighted the necessity for all immigrants to speak English to "start the process of their naturalization." In 1917 the Burnett Act required all new immigrants to pass a literacy test and barred immigration from Asia (exceptions being Japan and the Philippines). Simultaneously, the First World War brought in its wake unprecedented anti-German sentiments and nationalizing tendencies, leading towards monolingualism, with English being called the "one language in this country" by President Roosevelt (Nieto, 2009, p. 62). 
Significantly, the movement against bilingualism started peaking from the 1980 s to the present. Prominent examples include the Reagan administration's campaign against bilingual education; Senator S. I. Hayakawa's attempt (1981) to introduce a constitutional amendment aimed at adopting English as the official language of the US and his subsequent founding of "US English"; the rise of the English Only movement; the House of Representatives passing a similar bill in 1996 but failing to secure a majority in the Senate; California's Proposition 227 of 1998 ending bilingual programs throughout the state; and the No Child Left Behind Act of 2002 (Crawford, 2000, pp. 4-30; Donahue, 1995, pp. 112-141; Nieto, 2009; Ovando, 2003). Notably, the No Child Left Behind Act (NCLB) eliminated all references to bilingual education and imposed a testing system that relied on English-only instruction.

\section{Legacies of the Past}

In spite of the past history of forced assimilation of minority communities, America could not have been characterized as the land of dreams and opportunity and a haven for immigrants if some remarkable events had not happened. The democratic ideals of the American constitution, the abolition of slavery, the supremacy of the judiciary, and some remarkable legislation have all made America the democracy it was.

\section{Landmark Legislation}

Laws like Meyer v. Nebraska (1923), Farrington v. Tokushige (1927), and Mo Hok Ke Lok Po v. Stainbeck (1949) affirmed the rights of language-minority communities in the early and mid-twentieth century. However, the crowning glory of all legislations was the case of Brown v. the Board of Education of Topeka, which advocated desegregation in schools. This ruling paved the way for the AfricanAmerican community in their struggle for civil rights. It culminated in the passage of the Civil Rights act of 1964, Title VI of which proved to be a cornerstone for bilingual education in the US. The 1974 Lau v. Nichols ruling, the 1975 Lau Remedies, and the 1981 Castañeda v. Pickard are other landmark decisions that have served the needs and rights of language-minority students in the US (Nieto, 2009, pp. 63-4; Ovando, 2003, pp. 9-10).

\section{The First Two-way Bilingual School}

The Cuban Revolution of 1959 resulted in the arrival of a flood of exiled Cubans in Florida. Subsequently, a two-way bilingual program at Coral Way Elementary School in Florida was successfully established in 1963, with the help of federal assistance, the local teaching community, and the families. The previously existing bilingual schools were mostly catering to European immigrant populations. Thus, public and private schools teaching German had been established in Pennsylvania, Maryland, Ohio, Indiana, Illinois, Missouri, Nebraska, Colorado, and Oregon. Swedish, Norwegian, and Danish were taught in schools in Wisconsin, Illinois, Minnesota, Iowa, North and South Dakota, Nebraska, and Washington. Dutch was taught in 
Michigan, Polish and Italian in Wisconsin, Czech in Texas, French in Louisiana, and Spanish in the Southwest (Ovando, 2003).

\section{Increase in Numbers of Minority Communities in 1960-70}

The period of 1960 to 1970 saw a considerable increase in numbers of minority communities. The Immigration and Nationality Act of 1965 abolished the nationalorigin quotas and opened the way for a surge in immigration. It established annual visa caps for immigrants from Eastern and Western Hemisphere countries and preference categories based on family relationships and job skills.

Paradoxically, the wave against bilingual education reached its climax when modern-day research in bilingual education was pointing out all its advantages and immigration from Latin American and Asian countries was on the rise. Nieto (2009) and Ovando (2003) referred to the work of Krashen, Crawford, Greene, Hakuta, Padilla and Macedo, as opposed to the anti-bilingual arguments proffered by Keith Baker and Adrien de Kanter in this regard. This article will now explore the stances of opposition towards bilingualism and its associations with un-Americanism, as its detractors claim.

\section{Being Bilingual and Un-American}

In the era of Standard Ideology or monolingualism in the USA, being bidialectal or bilingual would not only affect social mobility, but would also reinforce the connection between English acquisition and loyalty. President Theodore Roosevelt emphasized the connection in 1926:

We have room for but one language in this country and that is the English language, for we intend to see that the crucible turns out our people as Americans, of American nationality, and not as dwellers in a polyglot boarding house. (quoted in Nieto, p. 62)

The ideology of English monolingualism in the US and its link with American identity could be perceived as a reaction against the large-scale immigration from the post-World War I era. A similar wave of immigration and the increase in minority populations as seen in the 2010 US Census reports has again been fomenting an atmosphere of mistrust against bilingualism among monolingual English speakers.

Bilingual speakers have been accused of being "disinclined to learn English or acquire literacy in English because of their loyalty to their native languages and cultures" (Wiley, 1996, p. 15). Such stigma and prejudices attached to languageminority or immigrant groups could actually prove counterproductive in the process of assimilation, as numerous investigations have shown. A study by Portes and Rumbaut (2006) of over 5000 second-generation children of immigrants including Asians and Chicanos found that children who experienced racial and ethnic discrimination were significantly less likely to identify as "American" (in Lee \& Suarez, 2009). The non-immigrant minorities also tended to construct an 
oppositional collective identity after being forced into their minority status (Ogbu, 1999; Porter \& Washington, 1993). The children of plantation workers in Hawaii felt uncomfortable using Standard English because it was associated with the European American oligarchy (Tamura, 1996, pp. 439-440). Thus, the forced use of the language of the majority culture often did not have the desired outcome.

Moreover, the myth that bilingualism negated American values was denounced by the Arizona High Court in its ruling on Yniguez v. Arizonans for Official English, 1995:

In our diverse and pluralistic society, the importance of establishing common bonds and a common language between citizens is clear. Equally important, however, is the American tradition of tolerance, a tradition that recognizes a critical difference between encouraging the use of English and repressing other languages... Freedom of speech is the foundation of our democratic process... By restricting the free communication of ideas between elected officials and the people they serve, article XXVIII threatens the very survival of our democratic society. (quoted in Crawford, 2000, p. 43)

A close analysis of the key terms used in the court ruling-diverse, pluralistic, common bonds, democratic society, the American tradition of tolerance, freedom of speech, free communication of ideas - show that bilingualism and Americanization need not be mutually exclusive notions. An American citizen could be bilingual and yet still American.

With notions of these legacies in mind, this article will go on to examine the implications of the 2010 Census reports to explore how an atmosphere of mistrust towards language-minority communities has marginalized the learners.

\section{Analyzing the Educational Attainments of Different Ethnic Groups}

A study of other available data from the Census Reports, namely, the American Community Survey and the Statistical Abstracts regarding the languages spoken by different communities of the American people, their educational attainments and dropout rates showed that the population growth of some of the minority communities was not commensurate with the growth of their educational achievements. The Hispanic population had, for example, grown by $43 \%$ between 2000 and 2010. However, the educational attainment of the community had not grown commensurately. Compared to other minority groups, the number of Hispanic high school and college graduates lagged behind (see Figures $5 \& 7$ below), and their number of high school dropouts had not decreased proportionately (see Figure 9 below). Also, even among Hispanics, the Mexican-American community seemed to be lagging behind the most, with the lowest numbers of high school and college graduates (see Figures $6 \& 8$ below). The number of Black students graduating from high school had improved drastically, from $31.4 \%$ in 1970 to $84.1 \%$ in 2009 (see Figure 6 below). However, the number of college graduates from the Black community had not improved likewise; it still ranked quite low (see Figure 8 
below). The number of high school dropouts in the Black community, though, had dropped considerably (see Figure 9 below).

The number of high school dropouts among White students was $11.3 \%$ in 1980 , decreasing to $6.5 \%$ in 2008; among Black students, $16.0 \%$ in 1980, dropping to $8.6 \%$; and among Hispanic students, $29.5 \%$ in 1980 , declining to $15.0 \%$ in 2008 . Among the Hispanic students of age 16-17 years (see Figure 10 below), the numbers have decreased considerably from $16.6 \%$ in 1980 to $3.1 \%$ in 2008 . However, among $18-21$ year-olds, it is still an issue: from $40.3 \%$ in 1980 to $20.0 \%$ in 2008 . Similarly among 22-24 year-olds, the numbers of dropouts have gone down from $40.6 \%$ in 1980 to $25.4 \%$ in 2008 (all figures come from the United States Census Bureau Statistical Abstracts of the United States, Tables 225 and 268, 2011).

\section{Observations}

1) The number of high school and college graduates was lowest among the Hispanic ethnic group.

2) The Mexican-American community was by far the lowest, in educational attainment, among the Hispanics.

3) The number of college graduates among Blacks was still quite low.

4) The number of high school dropouts among Blacks and Hispanics (16-17 years of age) dropped considerably.

5) Hispanic youths (18-24 years of age) were more likely to drop out of school than their younger counterparts.

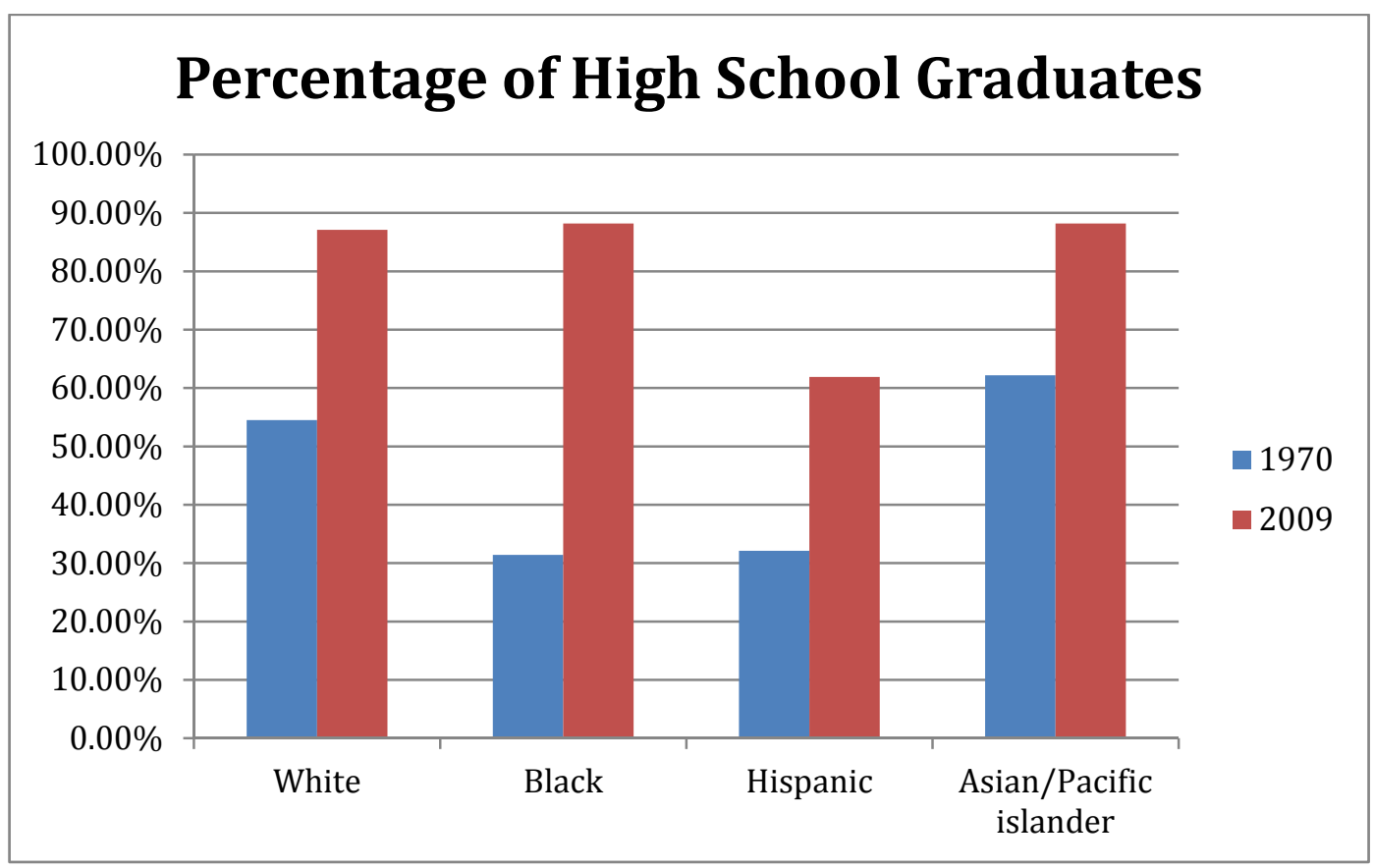

Figure 5. Percentage of High School Graduates, 1970 and 2009 


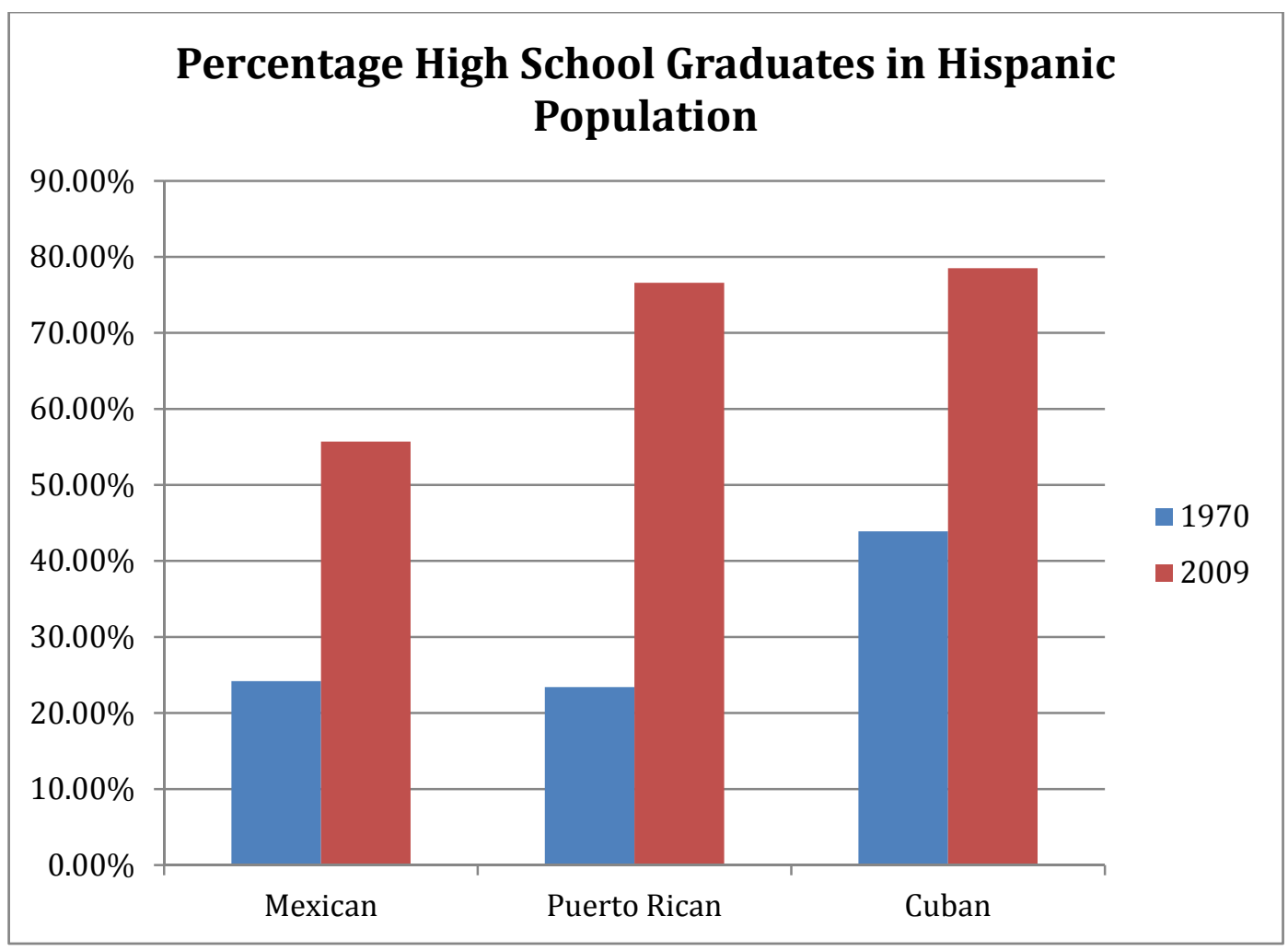

Figure 6. Percentage of High School Graduates in Hispanic Population, 1970 and 2009

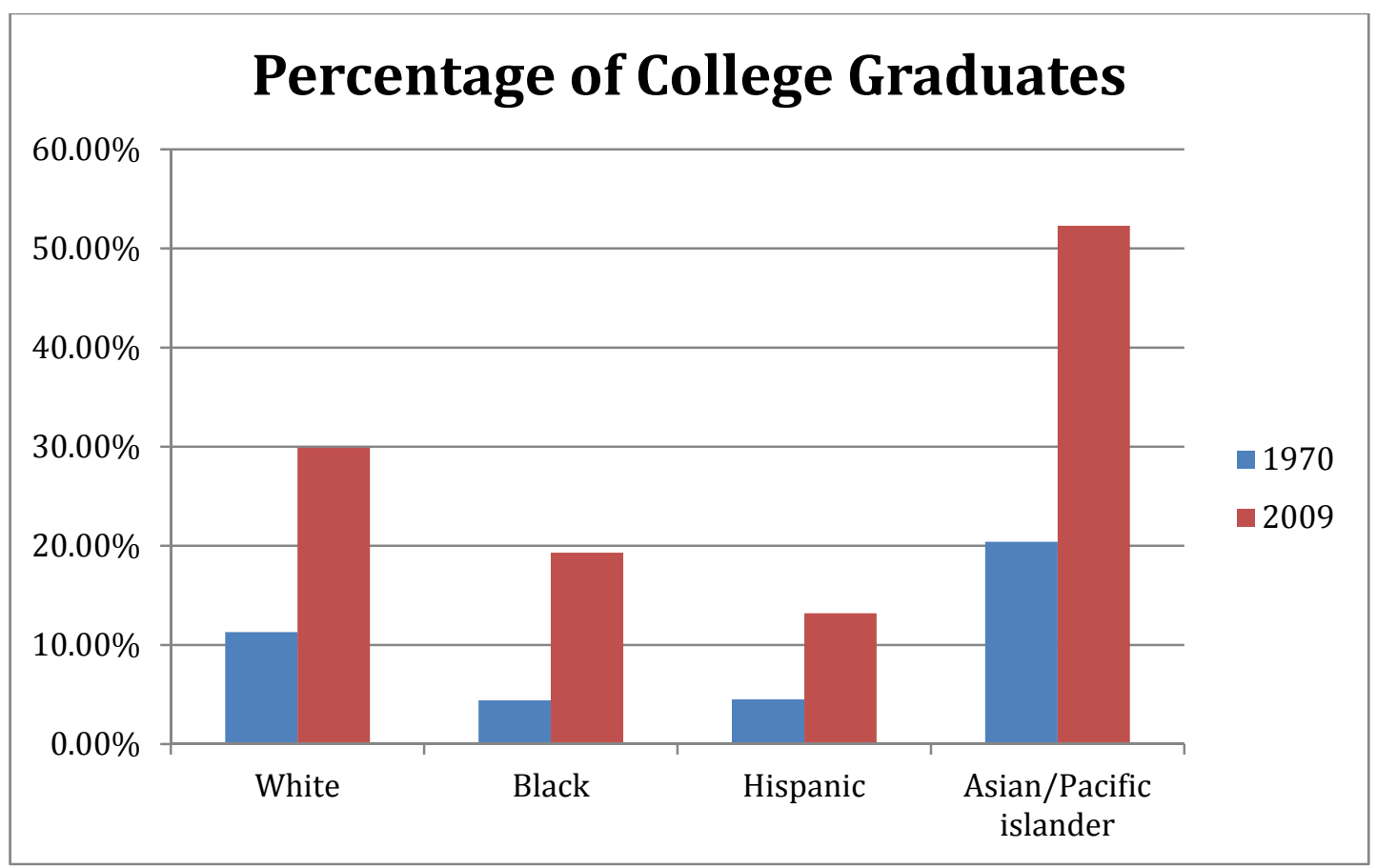

Figure 7. Percentage of College Graduates in US, 1970 to 2009 


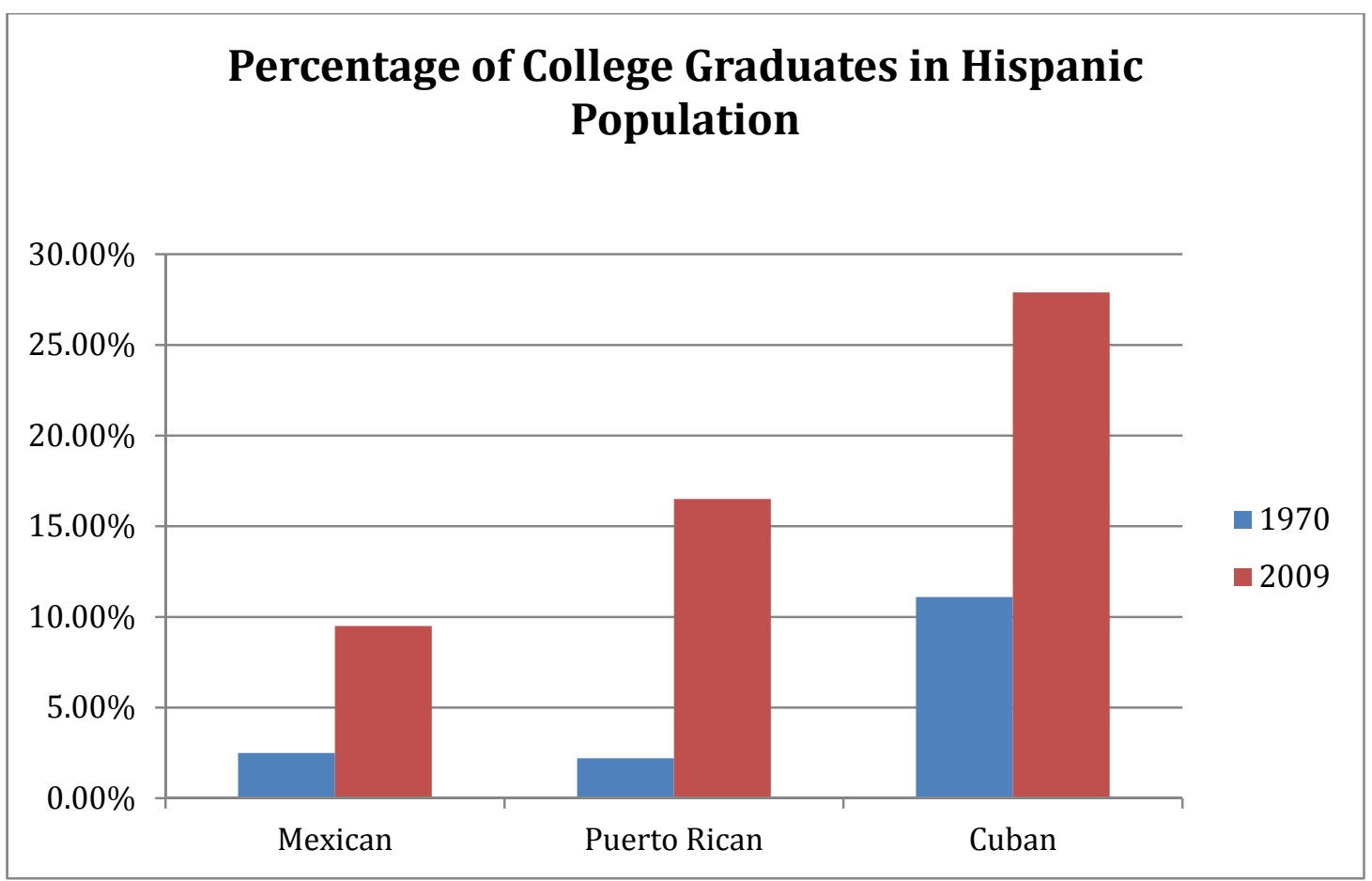

Figure 8. Percentage of College Graduates in Hispanic Population, 1970 and 2009

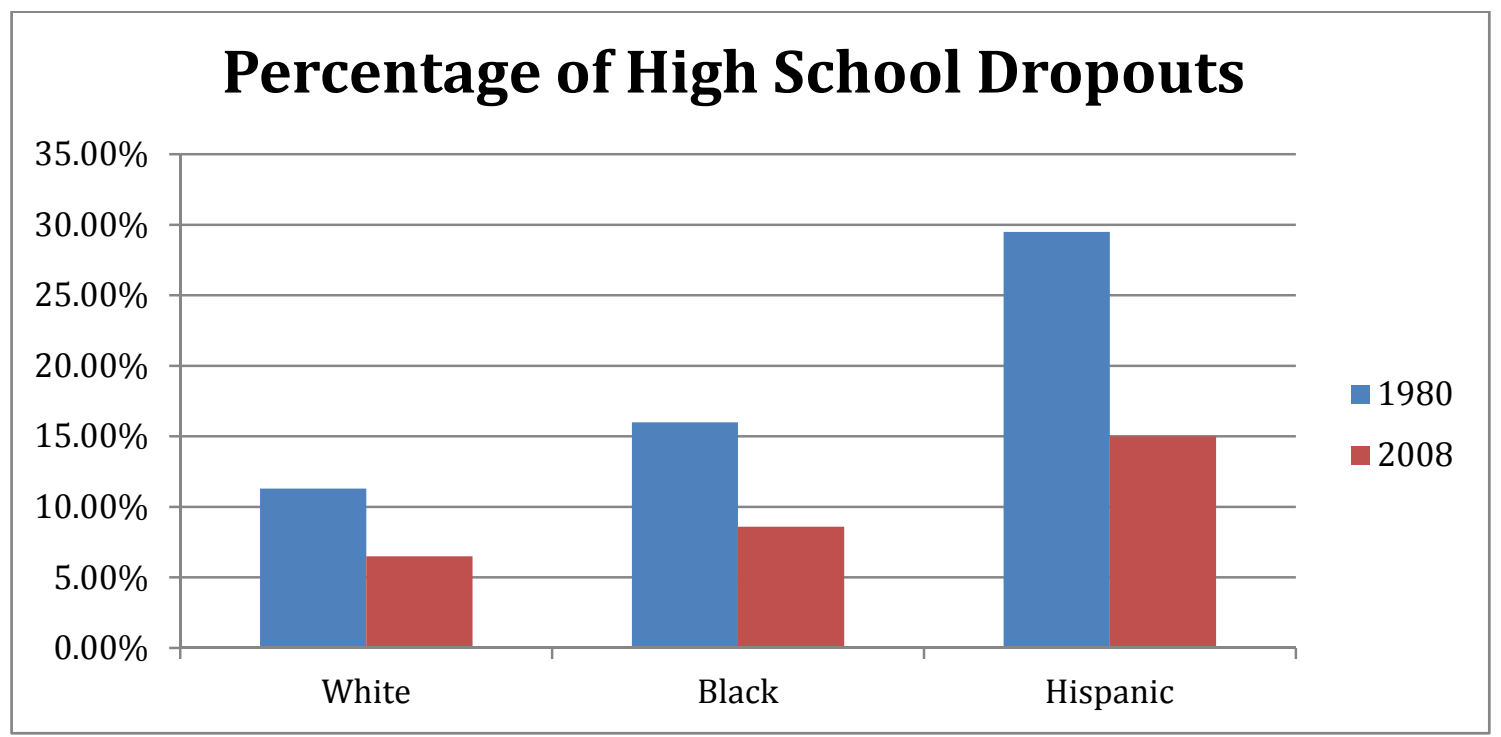

Figure 9. Percentage of High School Dropouts by Age, 1970 and 2009 


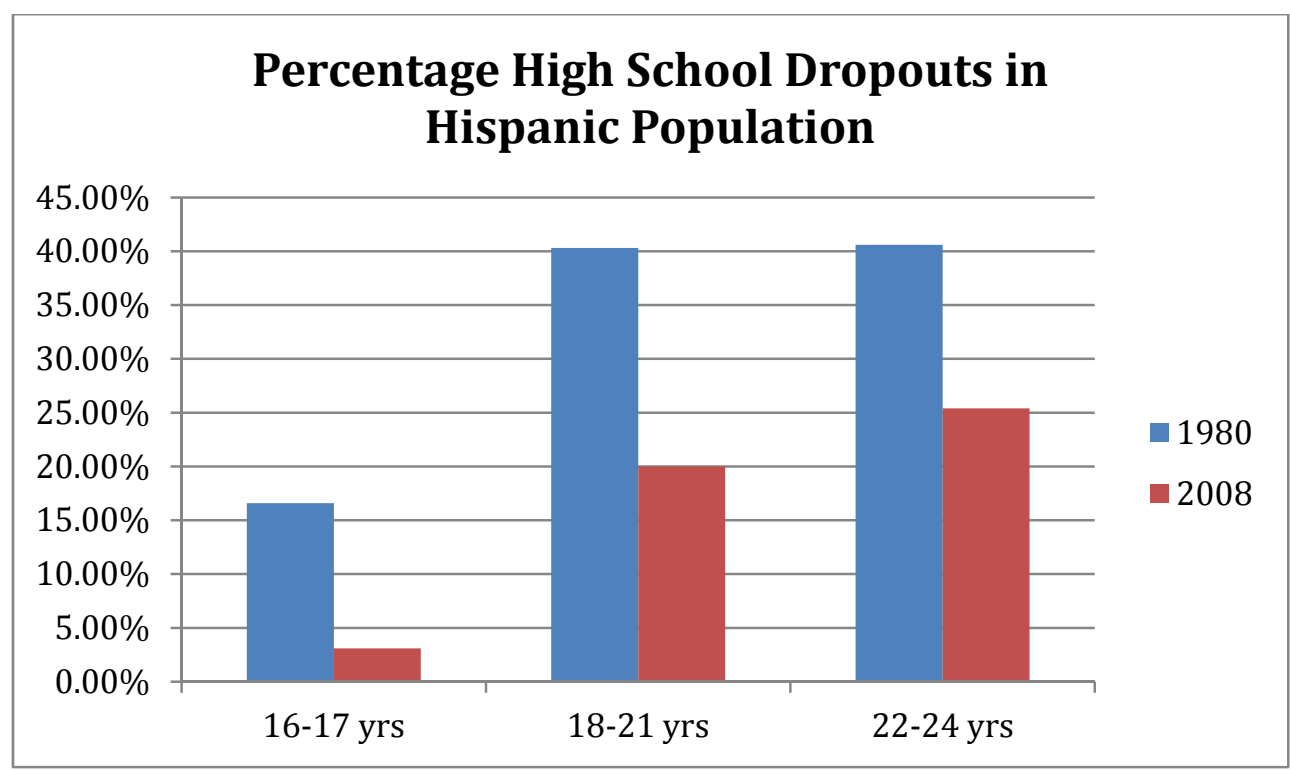

Figure 10. Percentage of High School Dropouts in Hispanic Population by Age, 1980 and 2008

\section{Attitudes Towards Bilingualism Need to Change}

From these figures, it is apparent that steps have to be taken to improve the language learning of bilinguals (and by extension bidialectals) in this changing demographic scenario. Otherwise, a sizeable part of the American population will be lacking in English proficiency.

The first way this could be done is by improving self-esteem among bilinguals (and by extension, bidialectals) by highlighting achievements of their home languages and cultures in schools. Delpit (2002) used the example of Africa to reinforce this point:

Those of us who teach must first make our students recognize their potential brilliance. When we know the real history of Africa - the Egyptian wonders of technology and mathematics, the astronomical genius of the Mali Dogon, the libraries of Timbuktu - then we can teach our children that if they do not feel they are brilliant, then it is only because they do not know whence they came. (p. 46)

Many elementary schools in the USA already study the history of the Native American people. Similar curricula could also be done with Asian and Central and South American cultures.

Secondly, the administration could help by granting proper status to the previously marginalized minority languages, as happened in Hawaii. The US Department of Education's Office of Bilingual Education and Minority Languages Affairs included Hawai'i Creole English as a language qualifying for federal funding under Title VII of the Elementary and Secondary Education Act. As a result, the Hawai'i State Department of Education's office of Bilingual/Multicultural Projects 
applied for and received funding in 1984-1989 for Project Holopono, aimed at selected elementary students, and in 1989-1993 for Project Akamai, aimed at selected high school students. Recognition by the government opened up new avenues and unlocked funds to revive a dying language (Tamura, 1996).

Moreover, for those who believe that English is losing its place of prominence in the US and that other languages are taking over, recent studies show otherwise. According to the results of the Language Spoken at Home survey done by the 2010 American Community Survey 1-Year Estimates, English continues to be the most prevalent language spoken in the US, spoken by $79.4 \%$ of the total population (speaking only English), compared to $20.6 \%$ speaking languages other than English.

Further, the monolingual communities have to be made aware of how bilingualism (learning a foreign language, in this case) could become an asset in an era of globalization. Learning another foreign language would give monolingual English speakers an edge and marketability in getting jobs in different parts of the world.

\section{English as a Tool of Global Communication in an Expanding World Order}

Instead of becoming defunct, as the English-only and English First advocates would like to believe, English has, in fact, become the dominant world language and the language of global communication. Kachru (1996) stated that "English is now the major instrument of initiating large-scale bilingualism around the world-being a bilingual now essentially means knowing English and using English as an additional language, as a language of wider communication" (p. 138).

Educational policymakers should therefore realize that it is time to return to the tolerant language policies of earlier days (Ovando, 2003). The handout of the 1999 National Association for Bilingual Education Conference highlighted that bilingual education could not be considered an isolated education program. It had to be re-embedded "in the larger frameworks of quality education and access for language-minority communities, promoting bilingualism for all (and foreign language policy), and ending the divisive tracking of children of different languages and skin colors and national backgrounds to different futures" (quoted in Ovando, 2003, p. 17).

The expanding world order can be discerned in Kachru's model of the "Three Concentric Circles." The figure is made up of the Inner Circle countries: UK, USA, Canada, Australia and New Zealand; the Outer Circle countries: Bangladesh, Ghana, India, Jamaica, Kenya, Malaysia, Nigeria, Pakistan, Philippines, Singapore, Sri Lanka, Tanzania and Zambia; and the Expanding Circle countries: China, Egypt, Israel, Japan, Korea, Nepal, Saudi Arabia, Taiwan, USSR and Zimbabwe (Kachru, 1996). Bhatt (2001) explains that the Outer Circle represents the spread of English in nonnative contexts, where it has been institutionalized as an additional language, with an estimated 150-300 million speakers. The Expanding Circle, with a steady increase in the number of speakers and functional domains, includes nations where English is used primarily as a foreign language, with an estimated 100-1,000 million 
speakers. Hence, the Outer and Expanding Circle countries could provide excellent employment opportunities.

\section{Models of Bilingual or Multilingual Countries: India and Singapore}

According to the United States Library of Congress, Federal Research Division and the Government of India portal, there are 22 different languages recognized by the Constitution of India, with Hindi as the official language. Article 343(3) empowers the Parliament to provide by law for continued use of English for official purposes. Hence, all the states have their own vernacular language, Hindi as the official language and English as another official language.

For some Indians, especially in the non-Hindi-speaking states in southern India, English is often the only language of communication with people from other parts of India. In most public schools, the medium of instruction is the state vernacular language, and English is taught as a second language. In private schools, the medium of instruction is English, and students have to study another vernacular language as well. Moreover, Hindi, the official language, is usually introduced in the curriculum around Grade 5/6/7, depending upon the state (Assam Education Department Rules and Orders; Maharashtra Board of Secondary Education, 2012; West Bengal Board of Secondary Education, 2010 Central Board of Secondary Education, Curriculum 2010; Indian Certificate of Secondary Education, Regulations).

According to the constitution of Singapore, Malay, Mandarin, Tamil and English were the four official languages in Singapore. The national language was the Malay language. The medium of instruction in all schools, public or private, was English. From Grade 1, English, accompanied by any other official language, was taught (Ministry of Education, Singapore, 2011).

\section{Problems Faced By India and Singapore}

These multilingual countries have also had their difficulties while implementing their language policies. In India, the dilemma had surfaced with the growth of a privileged class of learners from English-medium schools $10 \%$ of the total number of Indian schools, usually private schools), as opposed to the vernacular-medium free or subsidized schools run by the government (equivalent to the US public schools). Though the official language in India is Hindi, the makers of language policy in India had not been able to make all government schools adopt Hindi as the common medium, because of continued resistance from non-Hindi-speaking states. Thus, English continued to be an additional official language and the fluent English speaker enjoyed social mobility and socioeconomic status (Annamalai, 2005; Pattanayak, 1990, 1991).

In Singapore, the Speak Good English Movement guided by the ruling political leadership encouraged the use of Standard English in daily life, to counter the colloquial Singaporean English, known as 'Singlish'. Also, proficiency in English was associated with social prestige, mobility and economic status (Rappa \& Wee, 2006; Rubdy, 2005). Recent research has also pointed out that activities between 
different ethnic groups in public school classrooms did not result in similar multiethnic interaction during recess or playtime (Lee et al., 2004).

\section{How to Solve These Issues in an American Context}

1) The Indian public schools are paid for or subsidized by the government and hence often lack the infrastructure, facilities, or funds to employ English teachers with adequate qualifications. American public schools, on the contrary, benefit from municipal taxes, enjoy better funding and resources and are better staffed. Moreover, the Indian language scenario is complicated by the sheer number and variety of languages and dialects spoken in states, in contrast to the US.

2) The Singaporean identity was constructed on an "ideology of pragmatism" (Lai, 1995, p. 184) united with a rigid "CMIO (Chinese-Malay-Indian-Others)" brand of multiracialism, which equated each ethnic group in the city-state with a particular language, religion and culture, closely supervised by the government (Lai, 1995, p. 179; Clammer, 1998). American policymakers need to adopt a pragmatic point of view as well, in the realm of language. However, the concept of government supervision would have to be replaced by local administrative supervision, which matches the American federal principle.

\section{Recommendations in the Areas of Policy-making, Methodology and Curriculum}

1) Introduction of foreign languages at elementary school level is necessary and could go hand in hand with providing bilingual education for the languageminority groups. The choice of language could be made preferably by looking at demographics and language needs of school districts. After consultation with and feedback from the families of the students, such choices will also improve and expand the future career choices of monolingual students as well as preserve the cultural identity of the bilingual ones. Also, the introduction of an additional language at the elementary school level would mean the creation of more teaching jobs.

2) Recognizing "pluricentricity" of the English language, or "Englishes," as Bhatt (2001) termed them, might salvage the situation. Spanish could be declared a second official language, in states where a sizeable part of the population is Spanish-speaking. English dialects like AAEV, HCE, Chicano English and others should be given their proper status in the language world order, to make amends for years of marginalization. In this context, it is pertinent to look at the National Council of Teachers of English's (NCTE) language resolution of 1974 entitled "Students' Right to Their Own Language": "We know that American English is pluralistic. We know that our students can and do function in a growing multiplicity of language situations which require different dialects, changing interconnections of dialects, and dynamic uses of language" (p. 14).

3) In such a scenario, training both old and new teachers to deal with multi-ethnic or multicultural classrooms is of prime importance. A number of researchers 
have highlighted the teacher's role in this context. Spiecher and Bielanski (2000), recognizing Standard English as the language of social mobility and the discrimination resulting from it, zeroed in on the figure of the teacher in their quest to "combat the ubiquitous linguicism in [the] school system, [the] offices and society" with the help of the Prototype Theory applied to language usage. According to them, more research was needed on the dialects used by teachers in actual classrooms. The teacher's dialect "affect[s] his/her understanding of the students and their dialects, and ... affect[s] [their] ability to learn." Also, the educational community must be aware of "differences in the form and function of spoken and written language, of the way in which pupils' gender, social class, and ethnic group may affect the way they speak... and of the social attitudes toward linguistic diversity" (pp. 154-156, 164-165). Campano (2007) spoke about a "second classroom' that ran in tandem with and sometimes counter to the mandated curriculum." He visualized a "more horizontal model, [where] the classroom is conceptualized as a space of shared inquiry and the diversity of the student population as an epistemic advantage, rather than a hindrance" (p. 4).

4) Openness of teachers to learning new things about themselves as well as their learners was also significant. Heath (1996) discussed the teachers she was teaching in a graduate course and where they themselves became learners and their attitudes changed. Goodman's (2006) depiction of Doreen Noone Wheeler, the European-American teacher and her journey of misconception towards actual knowledge about the language competence of her student Jasmine, showed how teachers also need to keep on learning. Doreen selected Jasmine as the focal point of research, as her perception was that Jasmine always spoke AAEV and never used code switching, and this was affecting her education. However, as she started audiotaping Jasmine's class conversations and compared it with her writing samples, she realized that Jasmine was aware of the differences between formal and informal English spoken in different contexts, and this revelation influenced her attitude towards learners of other speech communities later. The NCTE's 1974 language resolution also underscored this issue.

5) Teachers need to ratify their book knowledge of language by living as minority speakers. They should be wholly immersed in a dialect group other than their own. Although such an opportunity may be difficult for some to obtain, less definitive experience may be obtained by listening to tapes and records, as well as interviewing sympathetic speakers who use minority dialects (NCTE, 1974).

6) Involving and enlisting help from immigrant communities in language classes could help in creating a comfortable, relaxed and productive learning environment. Delpit (2002) referred to Krashen's depiction of the "affective filter" operating when the affective conditions are not optimal, when the students are not motivated, or are overanxious. Therefore, the classroom should be made comfortable for all learners. Using the image of America as a melting pot of different immigrant nations, schools could celebrate a World Culture Day, where learners could trace and share their family history. Tracing one's 
genealogy is a prevalent practice in many countries, as the numbers of burgeoning websites can attest. Moreover, it would make a number of students think about where their ancestors came from-Europe, Mexico, South America or Asia. That would probably give them a distinctly different perspective if they thought of themselves as immigrants. Parents could chip in by bringing in food items characteristic of their region. Such events, followed by map pointing and "meaningful in-class discussions" (Lee et al, 2004, p. 133) could develop the imagination of students and increase awareness of other cultures. These attempts might seem superficial but they often make immigrant cultures seems less exotic and more mundane. For example, after tasting an Indian onion pakora, a non-Indian would recognize it as a variation of a Burger King onion ring and a piece of tandoori chicken as a spicy chicken wing. However, to cement in the knowledge of diversity with the notion of assimilation, age-old American values like loving your family, responsibility to your family, respect for other people, freedom of speech, and freedom of religion should be highlighted. Enlisting the help of the minority/immigrant learners' families and communities could help make the classroom more comfortable for such learners and acquaints learners coming from mainstream families with other cultures.

7) Spreading awareness among monolingual families in school districts regarding the benefits of bilingualism and of learning a second language from an early age is necessary. Highlighting the importance of an increasing need to improve one's language skills in the job market, especially in the context of the rising economic power of China, India, Brazil and other Latin American countries, and the continued deployment of troops in the Middle East and Southeast Asia, is required.

8) Using ESL/ELL strategies for dialectal English (AAEV, HCE, Chicano English) speakers and use of home language as part of the school curriculum are avenues that could be followed successfully. Use of language experience stories of the learners and of real-life situations could make the classroom a comfortable learning zone. Heffernan \& Lewison (2005) depicted the desegregation happening in a school lunchroom (pp. 25-34), where the children learned how to practice desegregation in reality. Using strategies that the learners understand and identify with-hairstyle, fashion, music, football, soccer, baseball, moviescould make learning more interesting and learner-appropriate. Also, as Chanda the teacher said in Goodman (2006), children's home language was part of being "themselves" (p. 150), and incorporating it in a classroom would be useful as well as meaningful. The 60 schools in the Los Angeles school district that have started a program called "Academic English Mastery," whereby the AAEV speakers could differentiate between AAEV and SAE without feeling degraded (PS 100, Watts, Los Angeles, CA), have clearly started following this path.

9) For bilinguals, the testing system should have translated versions in their native language.

Billings' (2005) strategy of highlighting the differences between the Black and White communities and then progressing towards further research to eradicate 
differences, could be expanded to include other ethnically and linguistically different groups in contemporary United States. He remarked that the way "to eliminate differences between the races is to first illuminate these differences ... some may argue that the separation of races for the purpose of the study only widens the divide, [but] this research can bring cultures together through explaining how Whites and Blacks [are] cognitively and behaviorally different. Once research demonstrates the ways in which the races differ, future research can begin to pinpoint why these differences exist" (p. 80).

The inherently pluralistic fabric of American society would benefit from taking a close look at the similarities and differences that characterize different ethnicities instead of stereotyping and categorizing them. Nieto-Phillips (2005) wrote:

The popular imagination is fed by two seemingly contradictory stereotypes: the wholesome, light-skinned Hispanic who believes in tradition, family, and the American Dream; and the lawbreaking, desperate, dark-skinned day laborer who will stop at nothing to enter the US even at great peril. Like the White and Black legends, these stereotypes can be found on the opposite sides of the same ideological coin...Hispanophilia...and Hispanophobia. (p. 253)

\section{Conclusion}

Taking into account the developing notion of association of monolingualism with Americanism (and of bilingualism with un-Americanism or anti-Americanism), this article explores the psyche of the language-minority student in an atmosphere of marginalization and mistrust prevailing in mainstream society. The 2010 reports of the US Census Bureau, meanwhile, highlight significant changes in the minority population of the country. With the help of other available data from the American Community Survey and the Statistical Abstracts regarding the languages spoken by different communities of American people, their educational attainments and dropout rates, it is observed that the population growth of some of the minority communities is not commensurate with the growth of their educational achievements.

The article underscores the need to change attitudes prevailing in society regarding bilingualism and bilingual speakers. Acknowledging the proper status of the minority languages and dialects and restoring the self-confidence of the minority learners would be a step in the right direction. Also, making the country aware of the advantages of bilingualism in a globalized world and making bilingual education a part of mainstream education (by introducing a foreign language) could alleviate feelings of resentment in monolingual communities. Moreover, the continuing and ever-widening hegemony of English throughout US and the world is an undisputed fact, and that should satisfy those who are worried that English will lose its prominence. A multicultural and multiethnic US should also learn from models of other multicultural and successfully multilingual countries like India and Singapore. 
The article recommends major policy, methodology, and curriculum changes:

1) The introduction of a foreign language at the elementary school level for monolingual speakers, which would go hand in hand with ongoing bilingual education programs for the language-minority groups. The choice could be made by consulting the demographics and language needs of school districts.

2) Recognition should be given to the plurality of the English language, and other dialectical forms of English should be used in the classroom.

3) The need to train teachers in handling multicultural classes; the role of teachers as learners, comprehending immigrant or minority cultures.

4) Enlisting help from immigrant and minority communities to make the classroom a relaxed space conducive to learning.

5) Using home language and language experience stories of the learners as texts in the class.

All communities must be aware of their respective language and ethnic differences, and also of the universal human values and the longstanding American values common to each of them. And for the lawmakers and policymakers, sweeping dust under the carpet by following soft options, marginalizing bilingual education by concentrating on short-term, politically-motivated gains is not useful any more. American traditions of plurality and democracy, of equal opportunity for all, must not be forgotten. Disguised discourses of race, language and power have to be brought out in the open. Until then, the future of this diverse land of dreams and opportunity will continue to drift and flounder.

\section{Recommendations for Further Research}

The changing demographic scenario in the US as shown in the Census report demands a new way of viewing bilingualism and bidialectalism. Bilingualism is now inextricably linked with globalization. Instead of perpetuating the history of marginalizing the language-minority groups by promoting English immersion classes, American society-and educational policymakers in particular-need to take a new look at the resources of growing bilingual and bidialectal communities and reform the existing education system. However, some issues remain unexplored and could therefore form the basis of future research:

1) The continuing dropout rate among minority students in the US, its link with their socioeconomic status, and the students' feelings of alienation across ethnicities; how their families could help them, with proper guidance from schools.

2) The use of ELL strategies in helping bidialectal students, instead of remedial classes.

3) The future of Singaporean English faced with the hegemony of SE. 
4) The future of the Indian education system: is the discrepancy between the English speakers and vernacular speakers widening? And what could be its implications?

\section{References}

Annamalai, E. (2005). Nation-building in a globalised world: Language choice and education in India. In Angel M. Y. Lin \& Peter W. Martin (Eds.), Decolonisation, globalisation: Language-in-education policy and practice. Clevedon, UK: Multilingual Matters.

Assam Education Department, Rules and Orders. Retrieved from http://aasc.nic.in/

Baker, C. (1993). Foundations of bilingual education and bilingualism. Clevedon, UK: Multilingual Matters.

Bhatt, R. M. (2001). World Englishes. Annual Review of Anthropology, 30, 527-550. doi: http://www.jstor.org/stable/3069227

Billings, A. C. (2000). Beyond the Ebonics debate: Attitudes about Black and Standard American English. Journal of Black Studies, 36(1), 68-81.

Campano, G. (2007). Immigrant students and literacy: Reading, writing, and remembering. New York: Teachers College Press.

Central Board of Secondary Education, India. (2012). Retrieved from http://cbse.nic.in/

Clammer, J. R. (1998). Race and state in independent Singapore, 1965-1990: The cultural politics of pluralism in a multiethnic society. Aldershot, UK: Ashgate.

Crawford, J. (2000). Anatomy of the English-only movement. In J. Crawford (Ed.), At war with diversity: US language policy in an age of anxiety (pp. 4-30). Clevedon, UK: Multilingual Matters.

Delpit, L. (2002). The skin that we speak. New York: New Press.

Donahue, T. S. (1995). American language policy and compensatory opinion. In J. W. Tollefson (Ed.), Power and inequality in language education (pp. 112-141). Cambridge: Cambridge University Press.

Goodman, K. S. (1992). I didn’t found whole language. The Reading Teacher, 46(3), 188-199.

Government of India portal (2011). Retrieved from http://india.gov.in/

Heath, S. B. (1996). Ways with words: Language, life, and work in communities and classrooms. Cambridge: Cambridge University Press.

Heffernan, L., \& Lewison, M. (2005). What's lunch got to do with it? Critical literacy and the discourse of the lunchroom. Language Arts, 83(2), 25-35.

Indian Certificate of Secondary Education (2011). Retrieved from http://www.icseindia.org 
Kachru, B. B. (1996). World Englishes: Agony and ecstasy. Journal of Aesthetic Education, 30(2), 135-55. Doi: http://www.jstor.org/stable/3333196

Lai, A. E. (1995). Meanings of multiethnicity: A case study of ethnicity and ethnic relations in Singapore. Oxford: Oxford University Press.

Lee, J. S., \& Suarez, D. (2009). A synthesis of the roles of heritage language in the lives of children of immigrants: What educators need to know. In T. G. Wiley, J. S. Lee \& R. W. Rumberger (Eds.), The education of language minority immigrants in the United States. Clevedon, UK: Multilingual Matters.

Lee, C., Cherian, M., Ismail, R., Ng, M., Sim, J., \& Chee, M. F. (2004). Children's experiences of multiracial relationships in informal primary school settings. In A. E. Lai (Ed.), Beyond rituals and riots: Ethnic pluralism and social cohesion in Singapore (pp. 114-145). Singapore: Eastern Universities Press.

Lew, J. (2004) The "other" story of model minorities: Korean American high school dropouts in an urban context. Anthropology \& Education Quarterly, 35(3), 303-323.

Macdonald, V. M. (2004). Latino education in the United States: A narrated history from 1513-2000. New York: Palgrave Macmillan.

Maharashtra Board of Secondary Education, State Curriculum Framework (2012). Retrieved from: http://www.msbshse.ac.in/newsite/newhome.html

Min, P. G. (1996). Caught in the middle: Korean communities in New York. Berkeley, CA: University of California Press.

Ministry of Education, Singapore (2011). Retrieved from http://www.moe.gov.sg/education/

National Council of Teachers of English (NCTE). Retrieved from http://www.ncte.org

Nieto, D. (2009). A brief history of bilingual education in the United States. Perspectives on Urban Education, Spring, 61-84.

Nieto-Philips, J. M. (2005). Afterword. In J. M. Nieto-Philips \& C. Schmidt-Nowara (Eds.), Interpreting Spanish colonialism: Empires, nations, and legends (pp. 249-256). Albuquerque: University of New Mexico Press.

Ogbu, J. U. (1999). Beyond language: Ebonics, proper English and identity in a Black American speech community. American Educational Research Journal, 36(2), 147-184.

Ovando, C. (2003). Bilingual education in the United States: Historical development and current issues. Bilingual Research Journal, 27(1), 1-24.

Park, I., \& Kim, J. (2007). Enculturation of Korean American adolescents within familial and cultural contexts: The mediating role of ethnic identity. Family Relations, 56(4), 403-412.

Pattanayak, D. P. (1991). Language, education and culture. Mysore, India: Central Institute of Indian Languages. 
Pattanayak, D. P. (Ed.). (1990). Multilingualism in India. Clevedon, UK: Multilingual Matters.

Porter, J. R., \& Washington, R. E. (1993). Minority identity and self-esteem. Annual Review of Sociology, Vol. 19, 139-161.

PS 100 in Watts, Los Angeles, California. (Video clip.) Retrieved from http://www.youtube.com/watch?v=h31qVYi70HE

Rappa, A. L., \& Wee, L. (2006). Language policy and modernity in Southeast Asia: Malaysia, the Philippines, Singapore, and Thailand. New York: Springer.

Rubdy, R. (2005). Remaking Singapore for the new age: Official ideology and the realities of practice in language-in-education. In A. Lin \& P. Martin (Eds.), Decolonisation, globalisation: Language-in-education policy and practice. Clevedon, UK: Multilingual Matters.

Spiecher, B. L., \& Bielanski, J. R. (2000). Critical thoughts on teaching Standard English. Curriculum Inquiry, 30(2), 147-169.

Tamura, E. H. (1996). Power, status, and Hawai'i Creole English: An example of linguistic intolerance in American history. The Pacific Historical Review, 65(3), 431-454. Retrieved from http://www.jstor.org/stable/3640023

United States Census Bureau Factfinder (2010). S1601, Language spoken at home by population 5 years and older, American community survey 1-year estimates. Retrieved from http://factfinder.census.gov/

United States Census Bureau, Population Division (2010). Table 4, Projections of the Population by Sex, Race, and Hispanic origin for the United States, 2010 to 2050 (NP 2008-T4). Overview of Race and Hispanic Origin: 2010. Release date: 2008. Retrieved from http://www.census.gov/

United States Census Bureau Statistical Abstract on Education (2011a). Table 225, Educational Attainment by Race and Hispanic Origin, 1970 to 2009. Retrieved from http://www.census.gov/

United States Census Bureau Statistical Abstract on Education (2011b). Table 268, High School Dropouts by Age, Race and Hispanic Origin: 1980 to 2008. Retrieved from http://www.census.gov/

United States Library of Congress, Federal Research Division. Country Profile: India. Retrieved from http://lcweb2.loc.gov/frd/cs/profiles/India.pdf

West Bengal Board of Secondary Education. (2010). Retrieved from file: http://wbbse.org/

Wiley T. G. (1996). Literacy and language diversity in the United States. Washington, DC: Center for Applied Linguistics. 